\title{
SOCIAL PATTERNS OF SMOKING AND ALCOHOL DRINKING AMONG YOUNG PEOPLE IN MOLDOVA
}

\section{Mariana CRISMARU1, Scientific Researcher, National Institute for Economic Research, Republic of Moldova}

This paper explores the incidence and individual determinants of smoking and alcohol drinking with a high prevalence among young people in Moldova. It goes beyond epidemiological approach and descriptive analysis and provides a sociological explanation for these risk-taking behaviours by linking them to local social context in which young people inhabit. The study is based on secondary data analysis of National Youth Survey of Moldova among 14-29 aged population (1112 respondents) carried out in 2016, commissioned by the EU-OECD Youth inclusion project and Ministry of Education, Culture and Research of the Republic of Moldova. Data were processed in SPSS. Multivariate analysis, adjusting for demographic co-variates was performed using logistic regression. The results of this study show that rates of male smoking and alcohol drinking are high, while rates in women are far lower. According to multivariate data analysis, gender and age are strong individual determinants for both health-risk practices. As well, another important predictor for these behaviors is young people's educational level - those with lower education level were particularly likely to smoke and drink alcohol. The study revealed also a strong interrelation between these health-risk practices. In paper is argued that high prevalence of smoking and drinking in male may reflect a normative structure for male socializing. Taking into consideration that strongest predictor variable overall is male gender, and strong relationship between heavy drinking and smoking, these behavioral factors might be responsible for the increasing in premature deaths among males in middle age.

Keywords: socio-demographic factors, incidence, prevalence, smoking, alcohol consumption, interdependence.

Acest articol explorează incidența și factorii individuali determinanți ai fumatului și consumului de alcool care au o prevalență ridicată în rândul tinerilor din Moldova. Această lucrare depășește abordarea epidemiologică și descriptivă și oferă o explicație sociologică, prin conectarea acestora la contextul social în care locuiesc tinerii. Studiul se bazează pe analiza secundară a datelor Sondajului Național al Tinerilor din Moldova în rândul populației de 14-29 ani (1112 respondenți) realizat în 2016 în cadrul proiectului de incluziune UE-OCDE și Ministerul Educației, Culturii și Cercetării din Moldova. Datele au fost procesate utilizând SPSS. Analiza multivariată, cu ajustarea co-variatele demografice a fost efectuată utilizând regresia logistică. Studiul arată că ratele de consum de tutun și alcool în rândul bărbaților sunt mult mai înalte comparativ cu ratele înregistrate în rândul femeilor. Conform analizei multivariate, sexul (masculin) și vârsta sunt factorii individuali determinanți pentru ambele practici comportamentale. Un alt predictor important îl constituie nivelul de educație al tinerilor - tinerii cu un nivel de educație mai scăzut au o probabilitate mai mare să fumeze și să consume alcool. Studiul a arătat o puternică interdependență între aceste comportamente cu risc pentru sănătate. Prevalența ridicată a fumatului și a consumului de alcool în rândul bărbaților reflectă o structură normativă pentru socializarea acestora. Luând în considerație faptul că cea mai importantă variabilă predictivă este sexul (masculin) și relația puternică dintre consumul ridicat de alcool și fumat, acești factori comportamentali ar putea fi responsabili de creșterea numărului de decese premature în rândul bărbaților de vârstă mijlocie.

Cuvinte-cheie: factori socio-demografici, incidența, prevalența, fumat, consum alcool, interdependență.

В этой статье рассматриваются распространенность и индивидуальные детерминанты курения и потребление алкоголя среди молодежи в Молдове. Анализ выходит за рамки описательного и эпидемиологического подхода и приводит социологическое объяснение поведению с риском для здоровья, связывая их с социальным контекстом, в котором проживает молодежь. Исследование основано на анализе вторичных данных Национального Опроса среди Молодежи в возрасте от 14 до 29 лет (1112 респондентов), проведенном в 2016 г. по заказу EU-OECD и

1 (C) Mariana CRISMARU, mariana_mascautan@yahoo.com

No. $1 / 2019$ 
Министерства Образования, Культуры и Исследований Республики Молдова в рамках проекта по вовлечению молодежи. Данные были проанализированы с использованием SPSS. Многофакторный анализ с учетом демографических ко-вариаций проводился с использованием логистической регрессии. Результаты данного исследования показывают, что показатели курения и потребления алкоголя среди мужчин намного выше, чем выше, чем среди. Многомерный анализ показал, что пол и возраст являются главными факторами, определяющие поведенческие практики с риском для здоровья. Еще одним важным предиктором такого поведения является уровень образования молодежи - люди с более низким уровнем образования чаще курят и употребляют алкоголь. Исследование выявило также сильную взаимосвязь между этими двумя поведенческими практиками с риском для здоровья. В статье утверждается, что высокая распространенность курения и употребления алкоголя у мужчин может отражать нормативную структуру их социализации. Принимая во внимание, что определяющим фактором является пол (мужской), а также учитывая тесную связь между алкоголизмом и курением, они могут быть причиной преждевременной смерти среди мужчин среднего возраста.

Ключевые слова: социально-демографические факторы, курение, потребление алкоголя, взаимозависимость.

DOI: https://doi.org/10.36004/nier.es.2019.1-11 JEL Classification: I12, I14 UDC: $316.4 .066(478)$

Introduction. Young people's health-related attitudes and behaviours, especially health-risk practices, and their determinants are major topics in both medical and psychosocial studies, while their findings and recommendations are crucial for informing the development of effective health education and health promotion policy, programs and practices.

The interest for studying health behavior has considerably increased over the past decades and is related to two main findings, namely that a great part of morbidity and mortality is caused by behavioral factors [1, 2, 3] and behavior can be 'influenced' or 'changed', which place a particular emphasis on prevention and education individual responsibility for health $[4,2,5]$. In other words, some illnesses and premature deaths could be considerably reduced if people would adopt lifestyles that promote wellness, such as eating healthful diets, exercising, avoiding binge drinking and not smoking.

Adolescence and youth ${ }^{1}$ are understandably considered as critical stages of individual's life. There are periods of major physical, psychological, and behavioural changes, as well as periods of socialization experience through participation in education and employment, formal and informal institutions and groups, and, generally, are shaped by social context they inhabit. All these might influence young people's perceptions and decisions on health-related behaviors [6], both protective and health-risk practices, which can be continued throughout the life. Most important that unhealthy behavioural patterns could determine their current and prospective health status and the risk for developing some chronic diseases in adulthood and lead to premature death [6, 4]. Moreover, early initiation of health-risk practices is associated with an increased risk of developing addiction, i.e. alcohol, nicotine [7, 4] that can negatively influence physical and mental health, obstruct school and occupational pathways, and affect interpersonal relations. These behaviors can also have a generally detrimental impact on quality of life.

This paper explores the prevalence and socio-demographic factors of smoking and alcohol drinking as most common health-risk practices with a high prevalence among young people in Moldova. It should be mentioned that alcohol consumption and smoking are currently some of the major challenges for public health, while the harmful use of alcohol and smoking are among the leading risk factors for disease burden in populations worldwide $[8,9,10]$.

As well, this study goes beyond epidemiological approach and descriptive analysis and provides a

1 There is considerable ambiguity in the definition of young people in the specialized literature and terms like young, adolescents, young adults are often used interchangeably. The National Youth Policy of the Republic of Moldova defines the youth population as those in the age group of 14-35 years. However, due to the availability of data, in this paper we refer to young people aged 14-29 years. 
sociological explanation for these risk-taking behaviours by linking them to local social context in which young people inhabit. Some scholars suggest that only by adopting a distinctively sociological as opposed to socio-epidemiological approach, behavioural factors can be appropriately situated, theorised and explained [11].

Theoretical approach

Health behavior is defined as any activity people perform to maintain or improve their health, regardless of their perceived health status or whether the behavior actually achieves that goal [2]. Generally, these can be health protective or confer health risk, may be intentional or unintentional and could have an immediate or long-term effect on people's health. As mentioned above, this study focuses on smoking and alcohol consumption among youth, especially on binge drinking, as most harmful for individual's health and investigate how these influence each other.

Traditionally, there are two main conceptual approaches for explaining health-related behaviours. The first one focus mainly on individual choice in explaining why people engage or not in health practices in terms of their reasons, knowledge, and health beliefs. It should be mentioned that belief models and other individualistic theories have been criticized for an overemphasis on individual choice and that have showed little impact on changing individual health behavior [12].

Sociological theories are opposed to the individualistic ones and point on structural factors and social context in which individual inhabit, recognizing a role for structure as well as agency $[13,14]$. It may be argued that sociological approaches reflect on inequality and power in society. From this point of view, health lifestyles are collective patterns of health-related behavior based on choices from options available to people according to their life chances" [13]. This definition within Contemporary Health Lifestyle Theory was developed by Cockerham $[13,14]$ and reflects Weber's (1978) seminal conceptualization of lifestyles that evokes life choices and life chances relate with one another in a dialectical relationship. Life choices are either empowered or constrained by a person's life chances and likely to be consistent with the capability to achieve them. According to Cockerham, structural life chances are influenced by material and social class circumstances: the degree of social stratification by age, gender, race/ethnicity; collective social relationships based on shared norms, ideals. Further, all these variables provide the social context for the socialization process and influence people's experiences throughout life that, and in turn shapes their capacity to make conscious, particular choices.

As it can be seen, person's life chances are largely described as being determined by social position and thus characteristic of particular status groups. This is also reflected in Bourdieu's (1984) concept of habitus. According to Bourdieu, lifestyles are generated by a habitus, which is a range of dispositions used by individuals to guide and evaluate their behavioural choices and options; it is formed through socialization and experience, and is shaped by the individual's class circumstances.

This approach has been used to explain the rise of mortality in the former Soviet countries, however, mainly focusing on Russia. It was argued that a habitus producing an enduring disposition toward a negative health lifestyle appears to have become normative for many people, especially males, and reproduced over time when regularly acted out in unhealthy routine drinking, smoking, and other practices $[15,16,17]$. As well, according to many scholars little or no social stigma is attached to heavy drinkers and smokers in some societies. While it can argued that such a habitus is ultimately harmful, the dispositions it produces may though be the normative lifestyle for a person's group or gender.

General youth situation

Youth in the Republic of Moldova stand in a special position within the population and the country's social and economic development. According to official statistics, young people aged 15-29 years accounts for about $22 \%$ of the total population. Beginning with 2011, the number of young people is reducing considerably and according to specialists' prognoses will continue to decrease [18]. Many national and international studies show that young people in Moldova face multiple and interdependent challenges. Thus, Youth Multidimensional Deprivation Indicator show that more than one-third (36.2\%) of young people suffer deprivations in multiple wellbeing dimensions (share of youth affected by multiple deficits in the areas of education, employment, health, civic participation and social inclusion at the same time) [19].

Youth integration in the labour market is of particular concern in Moldova. They are facing a range of challenges in their school to work transition. Furthermore, economic recession and political instability still reduce their chances to integrate into the domestic labor market. Currently, both the activity rates and 
employment rates are low for young people, while it is high the inactivity rate. According to the latest official statistics, the NEET rate (not in employment, education or training) in Moldova accounts for up to $29 \%$ among young people aged 15-29 years (2017), being one of the highest in Europe.

The general health status of young people in terms of both objective and subjective indicators performs better compared to other age groups. However, health challenges persist and are mostly related to health-risk behaviours. According to estimates, alcohol and tobacco consumption in Moldovan youth is high and is still higher than the EU average, thus threatening adolescent and youth physical and mental health. This is mainly explained by a reduced awareness of individual responsibility for health, lack of preventive health behaviour, insufficient and poor quality of educational programs on healthy lifestyle etc.

In this regard, it is important to update the data on prevalence and explore the socio-demographic factors of health-risk behaviours. This information could serve as a reference point on development national health education and health promotion policy, strategies and programs tailored for adolescents and young people.

Data and methods

The paper is based on secondary data analysis of National Youth Survey of Moldova among 14-29 aged population, commissioned by the EU-OECD Youth inclusion project and Ministry of Education, Culture and Research of the Republic of Moldova. From the methodological point of view, this survey offers enough cases for advanced statistical analysis due to a large sample ( $\mathrm{N}=1112$ respondents). The survey "Problems, values and aspiration of young people in Moldova" was carried out in June 2016 in 92 urban and rural localities.

Questions related to smoking and drinking habits and associated demographic and socio-economic variables were used for secondary data analysis. Data were analyzed using SPSS. Multivariate analysis, adjusting for demographic co-variates was performed using logistic regression. The advantage of logistic regression is that it calculates the probability of a discrete outcome for each dependent variable, rather than predicting the effects of several continuous independent variables on a single dependent variable. The statistics presented express the direction and magnitude of the relationship between an independent and dependent variable. Because several statistical tests were performed using a large sample size, statistical significance was taken as $\mathrm{p}<0.01$. The 95 percent confidence intervals associated with the odds ratios are also reported. A limitation of the study is that while the overall sample size is relatively large, the small size of specific population subgroups, particularly in young women, where the number of smokers and binge drinkers is smaller, reduced the power to detect significant differences.

Socio-demographic data on respondents. Table 1 gives some general demographic and socioeconomic characteristics of the study respondents. As mentioned, this survey is representative for the population of Moldova aged 14-29 years with a maximum standard error of $\pm 3 \%$.

Table 1

Distribution of demographic and socio-demographic variables

\begin{tabular}{|c|c|c|c|}
\hline Variables & & $\mathbf{N}$ & Valid, \% \\
\hline \multirow{2}{*}{ Gender } & Male & 524 & 47,1 \\
\hline & Female & 588 & 52,9 \\
\hline \multirow{3}{*}{ Age } & 14-19 years & 334 & 30,0 \\
\hline & 20-24 years & 366 & 32,9 \\
\hline & $24-29$ years & 413 & 37,1 \\
\hline \multirow{2}{*}{ Residence } & Urban & 473 & 42,5 \\
\hline & Rural & 639 & 57,5 \\
\hline \multirow{2}{*}{ Marital status } & Married / in partnership & 484 & 43,5 \\
\hline & Unmarried & 628 & 56,5 \\
\hline \multirow{3}{*}{ Education } & Primary / secondary school (low) & 466 & 41,9 \\
\hline & $\begin{array}{l}\text { Vocational / high school / post secondary } \\
\text { school (medium) }\end{array}$ & 419 & 37,7 \\
\hline & University / post university (high) & 226 & 20,3 \\
\hline \multirow{4}{*}{ Occupation } & Employed & 309 & 27,8 \\
\hline & NEET (not in employment, nor in education) & 376 & 33,8 \\
\hline & Pupil / student & 358 & 32,2 \\
\hline & Other & 69 & 6,2 \\
\hline
\end{tabular}

Source: Survey "Problems, values and aspiration of young people in Moldova", OECD and Ministry of Education, Culture and Research, 2016. 
Prevalence of smoking among young people

Smoking and heavy drinking habits are considered highly negative health lifestyle practices not only because of their strong relationship with specific diseases, such as different types of cancer, digestive and heart disease $[7,8,10]$, but also due to their high economic and social costs for individual and society. As it was mentioned, in order to inform policy makers on the population subgroups at higher risk, it is crucial to define the prevalence and determinants of these health-risk behaviours and their social context.

There is a consistent and large amount of evidence demonstrating that these health-risk behaviours are initiated in adolescence and youth [21]. This is especially true in case of smoking. Thus, according to many studies, over 90 percent of daily smokers started to smoke by the age of 30 years $[15,17]$.

In this study, young people were asked several question related to smoking: if they currently smoke (yes, daily or occasionally and not smoking), for smokers - the average number of cigarettes they smoke daily and a question measuring young people's attitudes toward smoking one cigarette or more per day (agreement or disagreement).

The table 2 shows the prevalence of smoking among young people. There were calculated age and gender specific prevalence, and and gender differences in smoking habits were assessed using chi-squared tests and two-sample t-tests. As data shows, rates of male smoking are high, while rates in women are far lower. Thus, about one third of young men aged 14-29 years are smoking daily and $13 \%$ - occasionally, while the prevalence among young women from the same age category is only $4 \%$ within daily and $2 \%$ within occasionally smokers. As it can be seen, the overall trend in smoking rates is for both male and female to increase with increasing age and the highest smoking rate is observed in male of 25-29 age category (41\%).

Table 2

Prevalence of smoking among young people, \%

\begin{tabular}{|c|c|c|c|c|c|}
\hline & & & Yes, daily & $\begin{array}{c}\text { Yes, } \\
\text { occasionally }\end{array}$ & No (non-smoker) \\
\hline \multirow[t]{4}{*}{ Male } & & 14-19 years & 13,7 & 12,4 & 73,9 \\
\hline & & 20-24 years & 34,1 & 15,6 & 50,3 \\
\hline & & $25-29$ years & 41,3 & 10,6 & 48,1 \\
\hline & \multicolumn{2}{|l|}{ Total } & 30,4 & 12,8 & 56,8 \\
\hline \multirow[t]{4}{*}{ Female } & & $14-19$ years & 1,2 & 1,7 & 97,1 \\
\hline & & 20-24 years & 3,6 & 2,1 & 94,3 \\
\hline & & 25-29 years & 6,7 & 2,7 & 90,6 \\
\hline & \multicolumn{2}{|l|}{ Total } & 4,1 & 2,2 & 93,7 \\
\hline \multirow[t]{4}{*}{ Total } & & 14-19 years & 7,2 & 6,9 & 85,9 \\
\hline & & 20-24 years & 18,1 & 8,5 & 73,4 \\
\hline & & 25-29 years & 22,5 & 6,3 & 71,2 \\
\hline & & & 16,5 & 7,2 & 76,3 \\
\hline
\end{tabular}

Source: Survey "Problems, values and aspiration of young people in Moldova", OECD and Ministry of Education, Culture and Research, 2016.

There are several aspects to be elucidated regarding the low smoking rates among young women and that could lead to its underestimation. Taking into consideration that questionnaires were administered in the respondents' home and many of them are still living with parents, young women may avoid answering honestly to smoking related questions, as this is still culturally unacceptable among women in Moldova, regardless of their age. On the other hand, it should be noted that statistical data for the last decades shows an increase in sales of slim, menthol and flavored cigarettes that are consumed mostly by women. As well, this trend is observed in marketing studies. Nevertheless, many studies that are based on self-reported smoking status have confirmed that compared with male smoking patterns, smoking in women is far less common and has a different age-specific pattern in Moldova compared to other countries [17]. Moreover, the 
rates have been far slower to rise than would be expected given male rates and trends observed in the western countries [17].

The number of cigarettes smoked per day are often seen as main indicator of dependence and is used to assess the levels of moderate to severe nicotine dependency, as well is an indic ation of smokers' ability to quit. The higher the number of smoked cigarettes per day, the higher is the level of nicotine dependency. In this context, it is worth mentioning that both most of young men and women that are smoking daily tend to smoke more than 10 cigarettes per day, while occasional smokers - under 10 cigarettes (Table 3).

Table 3

Number of cigarettes smoked per day, \%

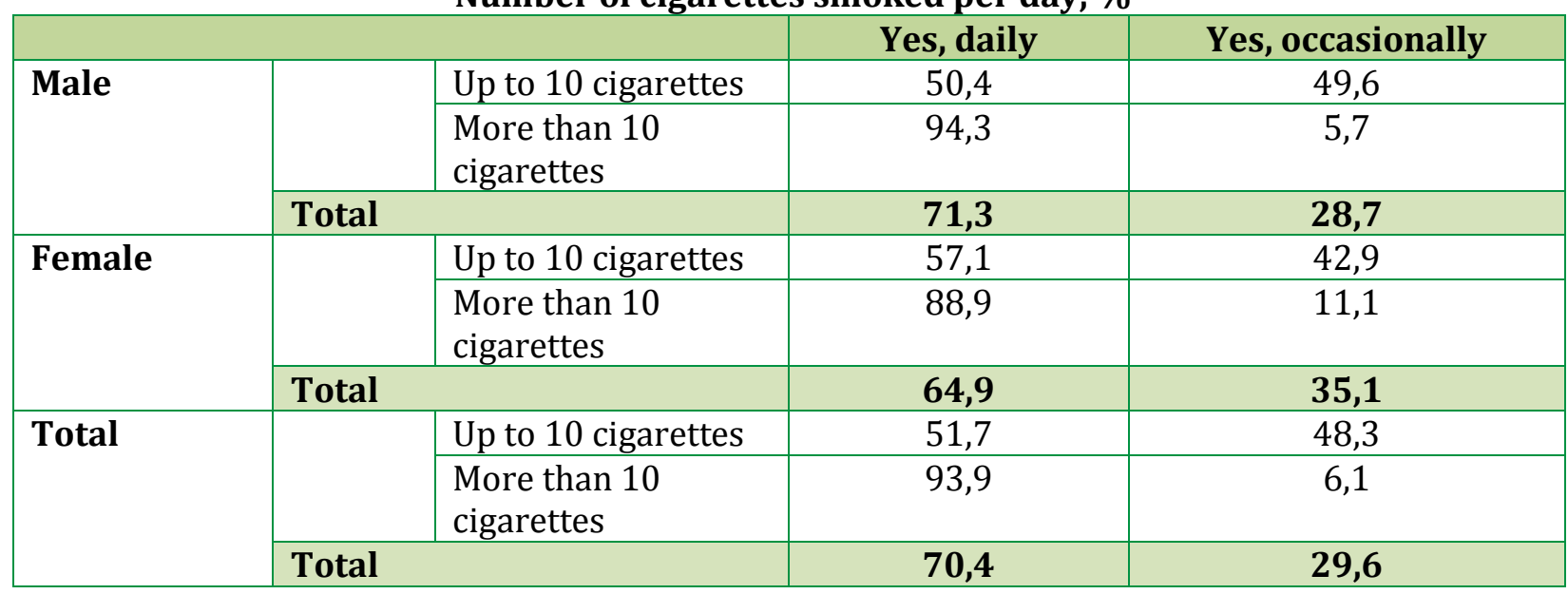

Source: Survey "Problems, values and aspiration of young people in Moldova", OECD and Ministry of Education, Culture and Research, 2016.

Prevalence of alcohol drinking among young people

Over a long period of time, Moldova was considered a traditional wine-drinking country, while current drinking patterns, especially of young generations, suggest a trend towards the homogenization of drinking habits and reveal the growing choices of alcoholic beverages available on the local markets due to opening to global alcohol markets [8]. Besides, there is well known that Moldova is amongst highest alcohol consuming countries in the world, even if a decreasing in the total alcohol per capita consumption is attested (from 21.6 litres in 2005 to 15.1 litres in 2016) [8]. Most important is that according to many national $[20,22]$ and international reports [8], the harmful use of alcohol is among the leading risk factors for disease burden in populations both in Moldova and worldwide.

This study included the questions on alcohol intake (any alcoholic beverage like wine, beer, vodka or other liquor) during the last 12 month; frequency of drinking; frequency of heavy drinking, defined as 6 glasses of wine (600 gr.) or more, or 6 cups (300gr.) of strong drinks (vodka, brandy) consumed on one occasion.

According to survey results, more than $70 \%$ of interviewed young persons reported that they consumed any alcoholic beverage like wine, beer, vodka or other strong spirits during the reference year. Those who never drank alcohol were defined as abstainers. As would be expected, the highest rate of drinking prevalence is among male of 20-24 years (72\%) and 25-29 years (81\%), while the highest abstention rates were found among female of $14-19$ years (67\%).

Table 4 shows the reported frequency of alcohol consumption by age groups and gender. The proportion of young respondents who drink alcohol frequently (at least two times or more per week) is quite high for male for both age groups $20-24$ and $25-29$ years (22\% in both cases). Moreover, the prevalence rates of alcohol intake two or four times per month is particularly high in males from 20 to 29 years (about 40\%). Overall, young women are less likely to drink frequently any alcohol beverages. Most of young women (75\%) reported that they drink alcohol once in a month or even rarely. 
Table 4

Frequency of alcohol consumption, $\%$

\begin{tabular}{|c|c|c|c|c|c|}
\hline & & & $\begin{array}{c}2 \text { times or } \\
\text { more per week }\end{array}$ & $\begin{array}{l}2 \text { or } 4 \text { times a } \\
\text { month }\end{array}$ & $\begin{array}{c}\text { Once in a } \\
\text { month or rarely }\end{array}$ \\
\hline \multirow[t]{4}{*}{ Male } & & 14-19 years & 8,5 & 36,2 & 55,3 \\
\hline & & 20-24 years & 22,0 & 39,0 & 39,0 \\
\hline & & $25-29$ years & 22,8 & 43,6 & 33,6 \\
\hline & \multicolumn{2}{|l|}{ Total } & 18,9 & 40,2 & 41,0 \\
\hline \multirow[t]{8}{*}{ Female } & & $14-19$ years & 7,1 & 12,5 & 80,4 \\
\hline & & 20-24 years & 3,3 & 19,7 & 77,0 \\
\hline & & $25-29$ years & 4,3 & 23,0 & 72,7 \\
\hline & \multicolumn{2}{|l|}{ Total } & 4,4 & 19,9 & 75,7 \\
\hline & & $14-19$ years & 8,0 & 27,3 & 64,7 \\
\hline & & 20-24 years & 12,7 & 29,4 & 58,0 \\
\hline & & $25-29$ years & 13,9 & 33,7 & 52,4 \\
\hline & \multicolumn{2}{|l|}{ Total } & 12,2 & 30,7 & 57,1 \\
\hline
\end{tabular}

Source: Survey "Problems, values and aspiration of young people in Moldova", OECD and Ministry of Education, Culture and Research, 2016.

As mentioned, in this paper a special attention is given to the frequency of heavy drinking situations among young people. Heavy episodic drinking is an important indicator of the pattern of alcohol consumption (defined as $600 \mathrm{gr}$. of wine. or more, or 300gr. of strong drinks at one occasion, and at least once per month) that can have a detrimental impact on individual's physical and mental health. As well, heavy drinking has been identified as an important risk factor in different types of injury, such as unintentional injuries (road traffic injuries, drowning, poisoning, falls) and intentional injuries (suicide, violence).

According to data, heavy drinking is clearly more frequent in men than in women (table 5). In this respect, it is noted that more than $70 \%$ of young males had at least one episode of heavy drinking during the year, while among them nearly $18 \%$ are consuming large amount of alcohol each month and 7\% - every week or even more. Despite an overall low prevalence rate of heavy drinkers among women compared to men, more than $40 \%$ of them had at least one heavy drinking occasions during the year.

Table 5

Frequency of heavy drinking episodes

(600 gr. of wine. or more, or 300 gr. of strong drinks at one occasion), \%

\begin{tabular}{|l|l|c|c|c|c|}
\hline \multicolumn{2}{|c|}{} & $\begin{array}{c}\text { Every week } \\
\text { and more }\end{array}$ & $\begin{array}{c}\text { Each } \\
\text { month }\end{array}$ & $\begin{array}{c}\text { Less than once } \\
\text { a month }\end{array}$ & Never \\
\hline \multirow{4}{*}{ Male } & $14-19$ years & 5,2 & 10,4 & 40,6 & 43,8 \\
\hline & $20-24$ years & 8,1 & 21,8 & 48,4 & 21,8 \\
\cline { 2 - 6 } & $25-29$ years & 6,1 & 18,9 & 52,7 & 22,3 \\
\cline { 2 - 6 } & Total & $\mathbf{6 , 5}$ & $\mathbf{1 7 , 7}$ & $\mathbf{4 8 , 1}$ & $\mathbf{2 7 , 7}$ \\
\hline \multirow{4}{*}{ Female } & $14-19$ years & 0,0 & 1,8 & 28,6 & 69,6 \\
\cline { 2 - 6 } & $20-24$ years & 0,0 & 3,3 & 42,1 & 54,5 \\
\cline { 2 - 6 } & $25-29$ years & 0,7 & 2,2 & 42,0 & 55,1 \\
\cline { 2 - 6 } & Total & $\mathbf{0 , 3}$ & $\mathbf{2 , 5}$ & $\mathbf{3 9 , 7}$ & $\mathbf{5 7 , 5}$ \\
\hline & $14-19$ years & 3,3 & 7,2 & 36,2 & 53,3 \\
\hline & $20-24$ years & 4,1 & 12,7 & 45,3 & 38,0 \\
\cline { 2 - 6 } & $25-29$ years & 3,5 & 10,8 & 47,6 & 38,1 \\
\cline { 2 - 6 } & Total & $\mathbf{3 , 7}$ & $\mathbf{1 0 , 7}$ & $\mathbf{4 4 , 2}$ & $\mathbf{4 1 , 4}$ \\
\hline
\end{tabular}

Source: Survey "Problems, values and aspiration of young people in Moldova", OECD and Ministry of Education, Culture and Research, 2016. 
As in case of smoking, the alcohol consumption according to some scholars tends to be underestimated (deliberately or otherwise) by survey respondents [8], while underreporting of alcohol intake could be higher in women. As a rule, the volume of drinking from surveys is compared to the volume derived from alcohol sales data. Due to the large amount of homemade wine consumption in Moldova that are not officially registered, this can be hardly achieved.

In many qualitative studies conducted both with young people and experts, the alcohol consumption comes out as one of the main behavioural risk behaviour among youth, especially among those not in employment, education or training - NEET. Thus, the results of NEET study in Moldova showed that health-risk behaviour, such as abusive alcohol consumption, is one of the major factor that places young people in this category or increases the risk of becoming NEET [5]. However, this has come out during the interviews with main local stakeholders, rather than during the interviews with targeted young people.

Determinants of smoking and heavy drinking and their interrelation

Several major determinants have an impact on levels and patterns of tobacco and alcohol consumption. While some are individual factors such as gender, age, education, etc., others are environmental factors, such as availability of alcohol, policy regulation on tobacco products and alcoholic beverages etc. This paper looks at individual determinants of smoking and heavy alcohol use among young people and investigates the relationships between these health-risk behaviors.

In this paper, current smokers were defined as young people reporting smoking daily, heavy drinkers were delimited as those who intake per occasion 600 gr. of wine or 300 gr. of strong drinks. The selected socio-demographic correlates of smoking and drinking included gender, age, marital status, area of residence, education level and occupational status. This analysis consists of a series of three statistical tests. The first examines the determinants of smoking, the second one explores the determinants of binge drinking, and the third investigates the relationship between smoking and drinking. Although variations in the alcohol consumed need to be examined cautiously due to the small numbers of respondents in some sub-groups, particularly in women. There are described only statistical significant variables ( $\mathrm{Sig} \leq 0,05)$.

Tables 6 and 7 show the distribution of the dependent and independent variables in the analysis. The variable of principal interest is gender and the results are noticeable. Young men are more than nine times $(\operatorname{Exp}(B)=9,288)$ likely than young females to smoke cigarettes daily and, among drinkers, they are nearly nine times $(\operatorname{Exp}(B)=8,503)$ more likely to be binge drinkers - to drink a large amount alcohol at one occasion and at least once a month.

The results for age suggest that young respondents aged 25-29 years are nearly four times more likely to drink frequently, be binge drinkers and they are significantly more likely to smoke daily. With respect to marital status, the results indicate that unmarried respondents are somewhat more expected to drink alcohol more frequently, while in case of smoking this variable is not statistically significant.

Table 6

Determinants of smoking (smoking daily)

\begin{tabular}{|c|c|c|c|c|c|c|c|c|}
\hline & \multirow{2}{*}{ B } & \multirow{2}{*}{ S.E. } & \multirow{2}{*}{ Wald } & \multirow{2}{*}{ df } & \multirow{2}{*}{ Sig. } & \multirow{2}{*}{$\operatorname{Exp}(B)$} & \multicolumn{2}{|c|}{ 95\% C.I.for EXP(B) } \\
\hline & & & & & & & Lower & Upper \\
\hline Gender (Male) & 2,229 & 250 & 79,786 & 1 & , 000 & 9,288 & 5,695 & 15,146 \\
\hline Age (14-19) & & & 13,078 & 2 & 001 & & & \\
\hline Age (20-24) & ,876 & ,316 & 7,683 & 1 & ,006 & 2,402 & 1,293 & 4,464 \\
\hline Age (25-29) & 1,305 & 361 & 13,077 & 1 & ,000 & 3,689 & 1,818 & 7,484 \\
\hline $\begin{array}{l}\text { Marital status } \\
\text { (single) }\end{array}$ &,- 402 & 242 & 2,761 & 1 & ,097 & 669 & ,416 & 1,075 \\
\hline $\begin{array}{l}\text { Place of } \\
\text { residence } \\
\text { (rural) }\end{array}$ &,- 808 & 197 & 16,869 & 1 & 000 & ,446 & ,303 & 655 \\
\hline $\begin{array}{l}\text { Education } \\
\text { (high) }\end{array}$ & & & 14,649 & 2 & ,001 & & & \\
\hline Education & ,983 & 281 & 12,213 & 1 & ,000 & 2,671 & 1,540 & 4,635 \\
\hline
\end{tabular}




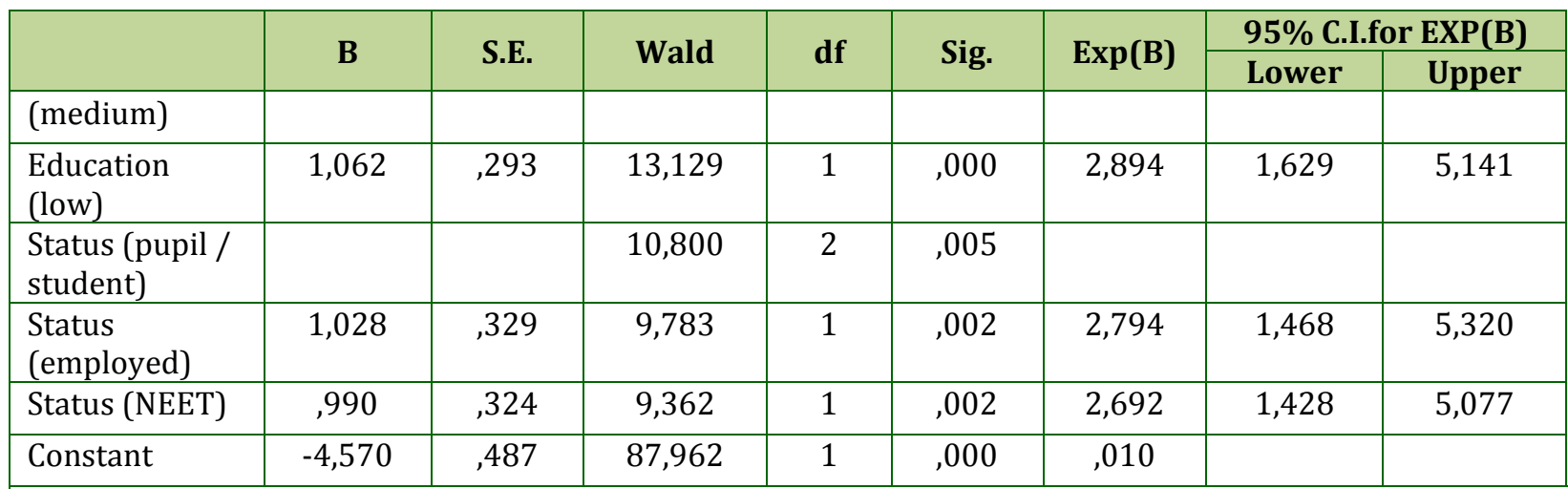

-2 log likelihood: 739,881a; Nagelkerke R Square: ,322; df: 8

a. Estimation terminated at iteration number 6 because parameter estimates changed by less than ,001.

Source: Survey "Problems, values and aspiration of young people in Moldova", OECD and Ministry of Education, Culture and Research, 2016.

The variables education and occupational status were quite powerful predictors overall of unhealthy lifestyle practices such as smoking and binge drinking. Higher educated persons are less likely to smoke or to drink high volumes of alcohol per occasion compared to less educated young persons. Thus, respondents with low level of education are nearly three times more likely to smoke daily and almost four times more likely to be binge drinkers. Occupational status performed better in case of smoking - employed young people or NEET youth had more chances to smoke daily compared to those involved in education. On the other hand, occupational status had no significant effect on binge drinking habits. Place of residence had no significant effects on any of the dependent variables, despite an overall perception that in rural area the prevalence of smoking and drinking among young people is higher.

Table 7

Determinants of heavy drinking

\begin{tabular}{|l|c|c|c|c|c|c|c|c|}
\hline & B & S.E. & Wald & df & Sig. & Exp(B) & \multicolumn{2}{c|}{$\begin{array}{c}\text { 55\% C.I.for } \\
\text { EXP(B) }\end{array}$} \\
\hline Gender (Male) & & & & & & & Lower & Upper \\
\hline Age (14-19) & 2,140 &, 368 & 33,800 & 1 &, 000 & 8,503 & 4,132 & 17,497 \\
\hline Age (20-24) & & & 9,420 & 2 &, 009 & & & \\
\hline Age (25-29) & 1,147 &, 402 & 8,130 & 1 &, 004 & 3,148 & 1,431 & 6,923 \\
\hline Status (single) & 1,336 &, 461 & 8,406 & 1 &, 004 & 3,802 & 1,541 & 9,378 \\
\hline Place of residence (rural) &,- 899 &, 348 & 6,672 & 1 &, 010 &, 407 &, 206 &, 805 \\
\hline Education (high) &, 415 &, 259 & 2,569 & 1 &, 109 & 1,514 &, 912 & 2,516 \\
\hline Education (medium) &, 510 &, 386 & 1,748 & 1 &, 186 & 1,666 &, 782 & 3,548 \\
\hline Education (low) & 1,263 &, 379 & 11,119 & 1 &, 001 & 3,537 & 1,683 & 7,433 \\
\hline Status (pupil / student) & & & 1,360 & 2 &, 507 & & & \\
\hline Status (employed) &, 200 &, 408 &, 241 & 1 &, 624 & 1,221 &, 549 & 2,715 \\
\hline Status (NEET) &, 422 &, 392 & 1,157 & 1 &, 282 & 1,524 &, 707 & 3,287 \\
\hline Constant & $-4,409$ &, 691 & 40,669 & 1 &, 000 &, 012 & & \\
\hline -2 log likelihood: 448,523; Nagelkerke R Square: ,253; df: 8 & & & & & \\
\hline
\end{tabular}

a. Estimation terminated at iteration number 6 because parameter estimates changed by less than ,001

Source: Survey "Problems, values and aspiration of young people in Moldova", OECD and Ministry of Education, Culture and Research, 2016.

One of the main objective of this paper is to elucidate the relationship between heavy consumers of alcohol and tobacco consumption. It should be noted that the link between these health 
risk behavior and its impact on individual's health is strong and it is well documented in many studies. For example, one of the main conclusion of Swedish longitudinal is that the relative risk of head and neck cancers from heavy use of alcohol was 4.2 and from regular smoking was 6.3 , while from both behaviours the relative risk has increased up to 22.1 [9]. This raises once again the issue of harms that can occur from heavy alcohol consumption and smoking.

Moreover, according to many scholars this relationship is "complementary" rather than "substitutive". Thus, a decrease of prices for alcohol beverages or tobacco products or increase in the availability of one of them is associated with an increase in the use of both products, against a "substitutive" relationship, where the use of the second product reduces when the first product becomes more available.

As results show, the interrelation between smoking and binge drinking is strong (table 8). Young people smoking daily are four times more likely $(\operatorname{Exp}(B)=4,211)$ to drink frequently (two or more times per week), while in case of regularly heavy drinking the relationship is more obvious. Thus, those who are heavy smokers are almost eight times more likely $(\operatorname{Exp}(B)=7,952)$ to be heavy drinkers. In this context, it may be argued that each of this health-risk practice become a risk factor for the other practice.

Table 8

Smoking daily and alcohol use determinants

\begin{tabular}{|c|c|c|c|c|c|c|c|c|}
\hline & \multirow[t]{2}{*}{ B } & \multirow[t]{2}{*}{ S.E. } & \multirow[t]{2}{*}{ Wald } & \multirow[t]{2}{*}{ df } & \multirow[t]{2}{*}{ Sig. } & \multirow[t]{2}{*}{$\operatorname{Exp}(B)$} & \multicolumn{2}{|c|}{$\begin{array}{l}\text { 95\% C.I.for } \\
\text { EXP(B) }\end{array}$} \\
\hline & & & & & & & Lower & Upper \\
\hline $\begin{array}{l}\text { Drinking once a month and } \\
\text { rarely }\end{array}$ & & & 21,525 & 2 &, 000 & & & \\
\hline $\begin{array}{l}\text { Drinking } 2 \text { or } 4 \text { times per } \\
\text { month }\end{array}$ & 748 & ,232 & 10,441 & 1 & ,001 & 2,113 & 1,342 & 3,327 \\
\hline $\begin{array}{l}\text { Drinking } 2 \text { or more times per } \\
\text { week }\end{array}$ & 1,438 & ,324 & 19,707 & 1 &, 000 & 4,211 & 2,232 & 7,946 \\
\hline Never binge drinking & & & 14,671 & 3 & ,002 & & & \\
\hline $\begin{array}{l}\text { Binge drinking less than once } \\
\text { a month }\end{array}$ &, 573 & ,240 & 5,713 & 1 & ,017 & 1,773 & 1,109 & 2,836 \\
\hline Binge drinking each month & ,865 & ,341 & 6,423 & 1 & ,011 & 2,376 & 1,217 & 4,638 \\
\hline $\begin{array}{l}\text { Binge drinking at least once a } \\
\text { week and more }\end{array}$ & 2,073 & ,596 & 12,109 & 1 & ,001 & 7,952 & 2,473 & 25,566 \\
\hline Constant & $-2,201$ & ,198 & 123,215 & 1 &, 000 & ,111 & & \\
\hline
\end{tabular}

Source: Survey "Problems, values and aspiration of young people in Moldova", OECD and Ministry of Education, Culture and Research, 2016.

\section{Conclusions}

The results of this study provide new information on the prevalence and socio-demographic determinants of smoking and drinking among young population in the Republic of Moldova. The data on these health-risk behaviours were obtained based on self-reported information, thus prone to some reporting bias, especially in case of young women.

The study highlighted major between-gender differences in smoking and drinking correlates in the targeted population. Gender and age was a strong determinant, and the observed lower likelihood of smoking and drinking at earlier ages is consistent with other surveys data. As well, young people with a lower education level were particularly likely to smoke and drink alcohol. The study revealed also a strong interrelation between these health-risk practices, while one of them may become a risk factor for other health-risk practices.

It may be argued that high prevalence of smoking and drinking in male in young adulthood reflect a normative structure for male socializing. As it was mentioned, these normative drinking dispositions become routine and internalized by the habitus, and they may be reproduced over generations by being constantly acted out, as Bourdieu (1984) explains in his work. Even that we make talk that a person always have a choice, group norms can take precedence. In his work, Bourdieu argues that people may have control over their lifestyle choices, but not necessarily over the social 
and psychological conditions channeling those choices in a certain direction as opposed to others they might take.

The study has also revealed that smoking is more prevalent among young men with low education level and NEET, which might indicate to the growing concentration of health-risk behaviours among socially and economically marginalized groups. This is especially true when the data are correlated with heavy drinking. It can be also explained by the fact that these categories are less responsive to tobacco and alcohol control policies.

Taking into consideration that the strongest predictor variable overall was gender (male) and strong relationship between heavy drinking and smoking, we may argue that these factors are responsible for the increasing in premature deaths among males in the middle age.

\section{REFERENCES}

1. WILKINSON, R., MARMOT, M. Social determinants of health: the solid facts. 2nd edition. World Health Organization. 2003. [Accesat 15.07.2018]. Disponibil: http://www.euro.who.int/_data/assets/pdf_file/0005/98438/e81384.pdf

2. SARAFINO, E.P. Health psychology: biopsychosocial interactions. Seventh edition. 2011. [Accesat 15.07.2018]. Disponibil: https://ultimatecieguide.files.wordpress.com/2017/03/sarafinohealth-psychology-biopsychosocial-interactions-edition-7.pdf

3. DARNTON, A. Reference Report: An overview of behaviour change models and their uses. Centre for Sustainable Development, University of Westminster. 2008, july. [Accesat 15.07.2018]. Disponibil:

https://pdfs.semanticscholar.org/6489/73efb254751f38fb6f434d432b9831179fa7.pdf?_ga=2. 120901832.1776374759.1565157621-91014933.1565157621

4. RIFKIN, S.B., LEWANDO-HUNDT, G., DRAPER, A.K. Participatory approaches in health promotion and health planning. London: School of Hygiene and Tropical Medicine, 2000.

[Accesat 11.08.2018]. Disponibil:

https://www.academia.edu/26421309/Participatory_Approaches_in_Health_Promotion_and_H ealth_Planning_a_Literature_Review

5. CRISMARU, M., GAGAUZ, O., BUCIUCEANU-VRABIE, M. Inclusion of youth not in Employment, Education of Training (NEET youth). Chisinau, 2017. [Accesat 11.04.2019]. Disponibil: https://www.md.undp.org/content/dam/moldova/docs/Publications/Inclusion_youth_NEET_ EN_web.pdf

6. ЛИСИЦИН, Ю.П. Общественное здоровье и здравоохранение. Москва: ГЭОТАР-Медиа, 2010. 512 c. ISBN 978-5-9704-1403-3.

7. CHERPITEL, C.J., BORGES, G. et al. Alcohol and injuries: emergency department studies in an international perspective. World Health Organization. Geneva: 2009 [Accesat 11.04.2019]. Disponibil: https://www.who.int/substance_abuse/msbalcinuries.pdf

8. Global status report on alcohol and health 2018. World Health Organization. 2018 [Accesat 17.08.2018]. Disponibil: https://apps.who.int/iris/bitstream/handle/10665/274603/9789241565639-eng.pdf

9. LEWIN, F., NORELL, S.E. et al. Smoking tobacco, oral snuff, and alcohol in the etiology of squamous cell carcinoma of the head and neck. 1998. [Accesat 11.04.2018]. Disponibil: https://onlinelibrary.wiley.com/doi/full/10.1002/(SICI)1097-

0142(19980401)82:7\%3C1367::AID-CNCR21\%3E3.0.CO\%3B2-3

10. WHO Framework Convention on Tobacco Control. Geneva, 2003. [Accesat 11.04.2018]. Disponibil:

https://apps.who.int/iris/bitstream/handle/10665/42811/9241591013.pdf;jsessionid=ABCA 67B7DD027EE06D1BF065C07F5111?sequence=1

11. HAERPFER, C., WALLACE, C., ABBOTT, P. Health problems and the transition from Communism in the former Soviet Union: towards an explanation. In: Perspectives on European Politics and Society. 2013, vol. 14, no. 4, pp. 460-479. [Accesat 11.07.2018]. Disponibil: https://doi.org/10.1080/15705854.2013.772751

12. BLUE, S., SHOVE, E. et al. Theories of practice and public health: understanding (un)healthy 
practices. Critical Public Health. 2014. [Accesat 15.07.2018]. Disponibil:

http://dx.doi.org/10.1080/09581596.2014.980396

13. COCKERHAM, W.C. Health lifestyle theory and the convergence of agency and structure. In: Journal of Health and Social Behavior. 2005, vol. 46, pp. 51-67.

14. COCKERHAM, W.C. The Contemporary Sociology of Health Lifestyles. In: The Palgrave Handbook of Social Theory in Health, Illness and Medicine, 2015, pp. 471-487. [Accesat 10.04.2019]. Disponibil: https://link.springer.com/chapter/10.1057/9781137355621_30

15. WALlACE, C.D., HAERPFER, C.W. Living Conditions, Lifestyles and Health. Routledge, 2010. [Accesat 10.04.2019]. Disponibil: https://abdn.pure.elsevier.com/en/publications/livingconditions-lifestyles-and-health

16. HINOTE, B.P., COCKERHAM, W., ABBOTT, P. The specter of post-communism: Women and alcohol in eight post-Soviet states. In: Social Science \& Medicine. 2009, vol. 68, no. 7, pp. 1254-1262. [Accesat 14.11.2018]. Disponibil: https://doi.org/10.1016/j.socscimed.2009.01.019

17. GILMORE, A., POMERLEAU, J. et al. Prevalence of smoking in eight countries of the former soviet union: results from the living conditions, lifestyles and health study. [Accesat 14.11.2018]. Disponibil:

https://pdfs.semanticscholar.org/7250/cd2406aa09c36a545161848ada6fef2bafbb.pdf

18. GAGAUZ, O., STRATAN, A., BUCIUCEANU-VRABIE, M. et al. Population situation analysis in the Republic of Moldova. Centre for Demographic Research, United Nations Population Fund (UNFPA). Chşinău: INCE, 2016. 175 p. [Accesat 15.05.2019]. Disponibil: https://moldova.unfpa.org/sites/default/files/pub-pdf/PSA_engleza.pdf

19. Youth Well-being Policy Review of Moldova. OECD Development Centre. EU-OECD Youth Inclusion Project. Paris, 2018. [Accesat 15.05.2019]. Disponibil:

https://www.oecd.org/countries/moldova/Youth_Well-being_Policy_Review_Moldova.pdf

20. KAP Survey - Knowledge, Attitudes and Practices regarding alcohol and tobacco consumption. Phase I-IV. World Health Organization. 2015, may. [Accesat 15.05.2019]. Disponibil: http://www.old2.ms.gov.md/sites/default/files/kap_survey-

knowledge_attitudes_and_practices_regarding_alcohol_consumption_phase_i_phase_ii_and_phas e_iii.pdf

21. Barriers to and Facilitators of the Health of Young People: A systematic review of evidence on young people's view and on interventions in mental health, physical activity and healthy eating: complete report. London: EPPI-Centre, 2002, vol. 2. [Accesat 10.04.2019]. Disponibil: https://eppi.ioe.ac.uk/cms/Portals/0/PDF\%20reviews\%20and\%20summaries/Vol\%202_Web .pdf?ver=2006-03-02-124349-650

22. TÎRDEA, Marcela, CIOBANU, Aangela, OBREJA, Galina. Nota de evidențe pentru politici. Informarea amendamentelor la legislaţia privind controlul alcoolului direcţionate spre reducerea consumului nociv de alcool în Republica Moldova. World Health Organization. Copenhagen: WHO, 2019. [Accesat 10.02.2019]. Disponibil:

https://mmpsf.gov.md/sites/default/files/mda_ebp_alcohol_rom.pdf

Recommended for publication: 11.06.2019 